\title{
PUBLIC ADMINISTRATION OF THE DEVELOPMENT AREAS IN UKRAINE
}

\author{
TATYANA GOGOL ${ }^{1}$ \\ State Agrarian and Engineering University in Podillia (Ukraine)
}

\begin{abstract}
This study aims at presenting complex information on the specifics of regional development and its management system, as well as the experience of forming and implementing the state regional policy in Ukraine. The information in the article is presented in the context of generally accepted notions and concepts of regional development and regional policy, along with the European experience and global trends, but first of all it is based on the realities of regions and rural areas in Ukraine and on its governance model. It has been determined that to establish an effective and competent public administration of rural development should be a priority, singled out as part of the state regional policy, socially orientated and coordinated with sectoral policies.

KEYWORDS: rural areas, public administration, regional policy, agricultural policy.
\end{abstract}

JEL CODES: H 73; H 79.

\section{Introduction}

The complexity of the public administration reformation of rural development requires to keep a complicated system, taking into account all aspects of this process, as each of its components play an important role in realization of strategic tasks of the new state agricultural policy. This might be confirmed by systematic underperforming of programs due to unusually large amount of goals, tasks and activities. Though in documents the entire spectrum of industry development problems is raised, it is impossible to decide on them during a five-ten year period, especially taking into account the socio-economic situation in the country. When developing these programs, we should keep the principle of concentration when separating the main directions and providing sufficient funding for appropriate measures.

A number of Ukraine scientists have researched complicated rural development issues on national level. From a particular point of view some aspects of rural development problems are studied in scientific publications (Bila, 2012; Ilyina, 2014; Kropyvko, 2016; Malik, Hvesyk, 2010, Mohylnyi, 2010; Orlatyi, 2012; Pavlov, 2015). Except for the spatial characteristics of scientific analysis, they include everything that operates in a particular area. In national scientific thought of the recent years, there has been a considerable interest in this field of scientific knowledge, as the increasing number of publications devoted to understanding of rural areas have emerged.

Purpose. The article is to define the innovative principles of the state agricultural and regional policy. The modern system of state regulation of rural areas in Ukraine is on the formation stage, therefore the justification of its theoretical and methodological foundations and development of practical recommendations for

1 Tatyana Gogol - State Agrarian and Engineering University in Podillia, Faculty of Economics, Department of management, governance and public administration. Scientific field: rural areas, regional development, public administration

E-mail: tgogol@ukr.net

Tel. +380679670914 
improving the existing practice is of utmost need. Moreover, introducing innovative regulation instruments and mechanisms, proved by international practice becomes a determining factor for their further development.

Object. The object of the research is the national policy of rural areas development.

The emergence of new promising areas of rural development and opportunities for their popularization indicated the direction of the research.

Tasks. The objectives of the research are: justification of the main directions and practical development of the state regulation mechanism for rural areas, justification of new approaches to the governance of socioeconomic processes in rural areas, which are fundamental changes in the principles of rural areas management - namely, in its decentralization.

Methods. The systematic approach was necessary, since the analysis of complex objects and problems, will inevitably lead to a systematic approach or theory. Empirical research was used too, as theoretical and methodological foundations were based on works of native and foreign scholars working in the field of rural development.

\section{Rural areas in Ukraine - current state}

Rural development policy consists of three major components: farmers' support, environmental protection, integrated projects for the rural infrastructure support. Ensuring the balanced functioning of rural areas becomes a necessary precondition for evolutionary development at the present stage of institutional and structural reforms in Ukraine.

The definition "rural areas" is understood as the most important part of the national economy, including the populated area outside the cities with its terms and resources, and the rural population in these areas.

According to this standard definition, more than $90 \%$ of the territory of Ukraine is "rural" and this area is a home for more than $30.8 \%$ of the Ukrainian population engaged in human activities, mainly in agriculture and forestry.

Despite the diversity of approaches to analysing these problems in scientific journals and a number of methodological, theoretical, analytical and applied researches on the state government mechanisms for the rural areas development is still not enough.

Territorial development is directly oriented to the person and formation of full living conditions and habitat for him / her, therefore, objectively, it has interdepartmental character and its task is to conform to multi-vector interests of various sectors.

An essential condition for the effective functioning of economy is development of rural infrastructure, including technical infrastructure. Without roads, efficient transport, communications, water supply and energy production in large areas is impossible. The lack of waste collection and sewerage systems threatens natural environment and the functioning of rural settlement. One of the main difficulties in the development of infrastructure in rural areas is large spatial dispersion. The total number of villages in Ukraine is 29.3 thousand, including 28.4 thousand villages and 0.9 thousand hamlets and settlements. However, rapid deterioration of the socio-economic situation of rural areas, that took place during the last decade, is also worth drawing attention to. To give an illustration, the amount of settlements with a population, that numbers over 500 , decreased by almost $10 \%$. In comparison, in more than half of the settlements the numbers decreased by 52.5\% - in Sumy, 45.7\% - in Chernigov, 42.8\% - in Kharkiv, 39.6\% - in Poltava; and in more than a third part of Luhansk, Kirovohrad, Dnipropetrovsk and Donetsk regions the population nowadays numbers only up to 100 people. At the beginning of 2014 the number of residents with up to 50 inhabitants accounted for $17.3 \%$ of the total number of rural settlements.

Rural areas are not only a place for agricultural production and farming, due to favorable environmental conditions they are attractive places for common living, which would be impossible to use without an effi- 
cient modern infrastructure. As a result of the support for civilization development in rural areas and construction of necessary infrastructure there, more people get better accessibility to the areas situated outside the city.

Table 1. Availability of social infrastructure objects in rural areas of Ukraine

\begin{tabular}{|c|c|c|c|c|c|c|}
\hline Indices / years & 1990 & 1995 & 2000 & 2005 & 2010 & 2014 \\
\hline $\begin{array}{l}\text { Housing stock: } \\
\text { - number of residential buildings, apart- } \\
\text { ments, million units }\end{array}$ & 5.9 & 6.2 & 6.2 & 6.1 & 6.1 & 6.0 \\
\hline - the total area million sq. $\mathrm{m}$ & 347.8 & 361.7 & 371.7 & 376.5 & 386.5 & 378.0 \\
\hline Pre-school establishments, thousand units & 12.6 & 10.9 & 8.9 & 8.4 & 8.9 & 9.3 \\
\hline $\begin{array}{l}\text { Secondary comprehensive schools, thousand } \\
\text { units: among them: }\end{array}$ & 15.1 & 15.2 & 14.9 & 14.3 & 13.2 & 11.9 \\
\hline Level I-(Primary) & 3.1 & 3.0 & 2.7 & 2.3 & 1.6 & 1.3 \\
\hline Level I-II (Primary and Basic) & 6.4 & 5.8 & 5.5 & 5.2 & 4.8 & 4.3 \\
\hline Level I-III (Complete) & 5.6 & 6.4 & 6.7 & 6.8 & 6.8 & 6.2 \\
\hline $\begin{array}{l}\text { Special schools (boarding schools) and } \\
\text { rehabilitation schools, units }\end{array}$ & 115 & 104 & 95 & 94 & 93 & 88 \\
\hline $\begin{array}{l}\text { Higher educational establishments, units: } \\
\text { among them: I-II accreditation levels }\end{array}$ & 101 & 121 & 112 & 113 & 118 & 21 \\
\hline III-IV accreditation levels & 18 & 20 & 20 & 22 & 23 & 16 \\
\hline Club establishments, thousand units. & 21.0 & 19.8 & 17.7 & 16.8 & 16.5 & 15.3 \\
\hline Libraries, thousand units & 18.7 & 18.0 & 15.7 & 15.1 & 14.9 & 13.5 \\
\hline Film demonstrators, thousand units & 22,2 & 13,6 & 5,9 & 2.5 & 1.6 & 0.8 \\
\hline Religious institutions, thousand units. & 5.9 & 8,8 & 11,3 & 13,5 & - & - \\
\hline Healthcare facilities, thousand units & 1.5 & 1.4 & 0.9 & 0.7 & 0.6 & 0.1 \\
\hline Outpatient clinics, thousand units & 1.6 & 1.8 & 2.4 & 3.1 & 3.4 & 0.6 \\
\hline Local health service centres, thousand units & 16.4 & 16.4 & 16.1 & 15.5 & 14.9 & 13.3 \\
\hline Pharmacies, thousand units. & - & 3.0 & 3.2 & 1.6 & 2.4 & 1.0 \\
\hline Ambulance stations, units & - & 231 & 203 & 181 & 175 & - \\
\hline Stadiums, units & 517 & 300 & 297 & 293 & 270 & 227 \\
\hline Gymnasiums, thousand units & 8.1 & 7.8 & 7.7 & 7.8 & 7.5 & 7.0 \\
\hline Swimming pools, units & 66 & 50 & 50 & 40 & 42 & 40 \\
\hline Shooting galleries, thousand units & - & 4.2 & 3.6 & 2.9 & 2.2 & 1.9 \\
\hline Sports fields and playgrounds, thousand units & 23.3 & 24.7 & 19.2 & 21.3 & 19.7 & 18.2 \\
\hline Football ground, thousand units & - & - & 8.4 & 8.4 & 9.0 & 8.3 \\
\hline Shops, thousand units & 60,5 & 48.2 & 33.5 & 19.0 & 13.4 & 8.8 \\
\hline Kiosks, thousand units & - & 3.5 & 3.6 & 2.9 & 3.0 & 1.8 \\
\hline Economy class restaurant, thousand units & 18.3 & 10.9 & 10.2 & 8.1 & 7.5 & - \\
\hline Telephone exchange, thousand units & 9.9 & 10.4 & 10.8 & 11.0 & 10.9 & 10.3 \\
\hline
\end{tabular}

Source: compiled by the author based on: http://www.ukrstat.gov.ua/.

According to the investigation of rural and urban dwellings, the former happened to compromise on quality. As of January 1, 2015, only $1 \%$ of the dwellings of rural households were equipped with central heating and those with individual heating accounted for $48.2 \%$ of households. Centralized gas supply is used within 3.2 million of households (53.2\%), and gas cylinder - within 1.9 million households (31\%). Moreover, $16.9 \%$ of dwellings are supplied with running hot water, $28.9 \%$ of dwellings are equipped with water delivery, $25.2 \%$ of households have sewerage, and $25 \%$ of households have a bath or shower. Summarizing the above stated information, the conclusion can be made that both the facilities within the dwellings and the provision of housing are directly dependent on the scope of the settlement. Unlike quantitative indices of 
households' living conditions, the improvement level of residential properties compromises on quality, while the size of the settlement decreases.

Although the absolute number of rural preschool educational establishments prevails in number over the alike urban institutions, it exceeds twice (2.3) in number of the pre-school seats in village, and three times (3.2) in number of children attending them. During the 2000-2014 period the number of pre-schools in rural areas decreased to 3.3 thousand units; and the pre-school attendance rate accounted for $41 \%$ of appropriate age children, while in urban areas it accounted for $63 \%$. The indices of the rural educational network condition mentioned above, indicate that the supply of the rural areas with schools accounts only for $43.8 \%$, i.e., there is only one school per 2.3 rural settlements.

As for the network of medical establishments in rural areas, it included 0.6 thousand outpatient clinics and 13.3 thousand health service centers. During the 2010-2014 period, the number of hospitals decreased five times (number of beds within them - 3.6 times), outpatient clinics - 5.7 times, health service centers 1.1 times. Similarly, due to the limited funding of sport support in rural areas, by January 10, 2015, the share of the rural population, being indulged in sport, accounted only for $5.6 \%$, which is lower than defined in the state programs.

While overcoming the crisis in social infrastructure, the elaboration of economic mechanism for regulation of social processes in rural areas is vital. Rural development should be based on the optimal combination of government regulations and market, clearly separating the powers and responsibilities of regional budget, local budgets and extra budgetary funds, funds of legal and individual persons, participating in the social programs' implementation.

However, the evaluation of rural areas in Ukraine is not definite yet. On the one hand, improved economic situation of farmers, increasing agricultural productivity and the sector's added value, improving infrastructure in rural areas has increased the number of households connected to the water supply and sanitation. However, there was a negative phenomenon too. There was observed the aging of the rural population and exodus of young people from rural areas. Despite the growing tendency in agriculture, the productivity of it in Ukraine still lags behind other countries.

Table 2. Labor productivity in agricultural enterprises (agricultural production per 1 employee, in 2010 prices; hryvnya)

\begin{tabular}{|c|c|c|c|c|c|c|}
\hline & 2005 & 2010 & 2012 & 2013 & 2014 & 2015 \\
\hline Agricultural production - total & 72621.9 & 132680.4 & 159679.0 & 201216.9 & 227753.4 & 223309.9 \\
\hline \multicolumn{7}{|l|}{ including: } \\
\hline crop production & 86198.1 & 133603.0 & 155543.8 & 202220.5 & 228884.7 & 218768.0 \\
\hline livestock production & 47992.8 & 130473.7 & 171798.3 & 198185.6 & 224105.1 & 237990.0 \\
\hline
\end{tabular}

Source: compiled by the author based on: http://www.ukrstat.gov.ua/.

An important factor in the development of rural areas is an agricultural enterprise, which is a kind of business activity. In the Ukrainian agriculture there exist the following types of economic activity enterprises: 45379 units of legal persons and their separate subdivisions, which are involved in growing the annual, biennial and perennial crops, plant reproduction, animal production, mixed farming and supporting agriculture and post-harvest activities; 4241.6 thousand units of households, the residence of which is registered in rural settlements and their members were given land plots according to the current legislation with a specialpurpose designation "for conducting private peasant holding" (including plots, which before had been given with a special-purpose designation "for conducting private subsidiary small-holding"). 
Table 3. Number of agricultural enterprises, by the organizational and the legal forms of business and individual farms

\begin{tabular}{|l|l|l|l|l|l|l|}
\hline & \multicolumn{1}{|c|}{2005} & \multicolumn{1}{|c|}{2010} & \multicolumn{1}{c|}{2012} & \multicolumn{1}{|c|}{2013} & \multicolumn{1}{|c|}{2014} & \multicolumn{1}{c|}{2015} \\
\hline Total, units & 57858 & 56493 & 56056 & 55630 & 52543 & 45379 \\
\hline Business partnerships & 7545 & 7769 & 8235 & 8245 & 7750 & 7721 \\
\hline Private enterprises & 4112 & 4243 & 4220 & 4095 & 3772 & 3627 \\
\hline Co-operatives & 1373 & 952 & 848 & 809 & 674 & 596 \\
\hline Private farms & 42932 & 41726 & 40676 & 40752 & 39428 & 32303 \\
\hline State enterprises & 371 & 322 & 296 & 269 & 228 & 241 \\
\hline Enterprises of other types of business & 1525 & 1481 & 1781 & 1460 & 691 & 891 \\
\hline $\begin{array}{l}\text { Total number of farms, thousand } \\
\text { units }\end{array}$ & 4915,3 & 4540,4 & 4915,3 & 4540,4 & 4301,8 & 4241,6 \\
\hline
\end{tabular}

Source: compiled by the author based on: http://www.ukrstat.gov.ua/.

The World Bank confirmed and identified these problems by ranking them according to the importance: the primary factor is the level of technical infrastructure and equipment in rural areas that has direct impact on the development of them and agriculture; among other documented problems there was mentioned the quantitative level of agricultural production; and then the overall development opportunities in these areas that attract domestic capital and investments (Wyporska, Mosiej, 2010). However, the EU policy on infrastructure development that has been conducted for many years, aims to create conditions for its availability in all EU countries, in order to diminish the civilization gap, separating rural areas from the urban ones, as well as to create equal opportunities for competitiveness in rural areas.

Population in the world developing regions will remain predominantly rural until 2020, then, the size of the rural population is expected to decline due to slower population growth and rapid urbanization in most countries. The main object of this development is the foundation of national wealth - the land.

So that to achieve this goal, it is necessary to distinguish the following tasks:

- To form an effective system of public authority in the regions, capable to provide sustainable rural development.

- To establish effective mechanisms of representation of regional interests and regional-local communities at the national level.

- To ensure the consideration of regions' identity and their competitive advantages in the formation and implementation of the state regional policy.

- To strengthen the influence of local government administrations on rural development, improving the quality of public services and decision-making in rural development.

- To develop the legal support of local government administrations for strengthening the financial and economic independence of communities.

Thus, transformation processes in the agricultural economy should result in the formation of a qualitatively new system of state regulatory relations, capable to self-regulate in the dynamic transformational phases and contradictions.

\section{Modernization of rural development policy}

Having analysed the legislation on the governing of rural development it should be noted that a number of regulations of different legal force were adopted, defining a system of government measures for to overcome the crisis. The aim was to create an appropriate standard of living for the rural population in the light of population decline in the village. Though those programs had clearly defined goals and ways to achieve 
them but despite the progressive orientation of the developed and adopted legislation they did not give the expected positive results.

State administration of the development of rural areas is a form of activity performed by the authorities and local government administrations, which finds its expression in the adoption of the relevant legal acts, concepts, strategies and programs aimed at solving social and economic problems of rural areas.

However, despite a large amount of measures, implemented at the state level for providing stabilization and further social and economic development of rural areas, the situation in this area is still difficult due to the following reasons:

- Absence of a single central executive state authority which would be responsible for the development of rural areas in Ukraine with priority attention on social issues, integrated and stable development of rural areas. Yet in the structure of the Ministry of Agrarian policy and provision of Ukraine, there is a department for scientific and educational support of rural development but its functions are very limited;

- Irrational distribution of powers between the local government administrations and the local executive agencies;

- Inadequacy of the existing territorial authority, administrative and territorial system of the country to its new issues of development;

- Lack of real opportunities for: self-realization of citizens, the policy of stable development of rural areas, incentives to attract citizens to the government; as well as lack of accountability of the local government administration to its citizens.

The modern system of the state regulation of the rural Ukrainian areas is in the formation phase, yet the arguments for its theoretical and methodological foundation as well as development of practical recommendations for its improvement, introducing progressive instruments and mechanisms, proved by international practice, is a crucially important factor for their further development.

Today the term "modernization" becomes quite popular and often one can notice a deliberate attempt to implement qualitative changes in the Ukrainian society based on the experience of advanced countries. The main problems of modernization and possible solution issues are: withdrawal of economy from the political control; creation of an open social structure with institutions ensuring mutual security; establishment of an effective system of local government. Modernization of the state is a system of changes that occurs when pre-paradigm (model) of a state ceases to act and thus its further development stops.

Therefore, we consider modernization as a specific ideology around which specific reforms leading to large-scale qualitative changes are implemented.

Development of rural areas is a complex terminological structure that first of all is the scientific abstraction. Firstly, it needs differentiation of the general concept into components, then determination of their nature and content. The research made it possible to classify the system-establishing factors of the concept "rural area", namely as: spatial and geographical, anthropological, resource production, settlement and network, organizational management (Yermolenko, 2010). The most complete and the most meaningful definition of the concept "rural area" should include all of these factors, although, an anthropological factor is certainly in priority. The leading role in overcoming the problems of sustainable development in rural areas should first of all belong to the measures that ensure sustainable social development of these areas.

Hence, the territory is considered not only as a recipient, where different subjects operate independently, but rather as the development affecting factor.

Even at the beginning of $21^{\text {st }}$ century Ukraine remains the rural country searching for sustainable development within different regions. So that to understand the essence of rural areas in the context development programs and their conceptual issues, it is important to understand the irreversible relation between the social part of the Ukrainian village development and the state regulation of rural development, as to have opportunities to get the other important results of it. We consider that rural areas should be logically defined as a synthesized concept with structural elements of the population, environment, economic entities, public administration and local government (Gogol, 2009). 
Concluding, the future political decentralization at the regional level should be aimed at strengthening the capacity of local communities, their adaptation to the specific conditions of economic and social development, established in Ukraine. It would be the most appropriate type of decentralization in the current socio-economic conditions.

\section{The formation and implementation of the state policy for rural development}

The current global challenges and trends followed by definite problems of the territorial development of Ukraine determinate the necessity to develop a new public policy and create new opportunities for the rural areas development. Considering the given conditions it is necessary to form and implement a solid public policy based on the basic long-term goals, i.e. competitiveness, environmental protection, diversification of economic activities, development of local communities. However, the policy should be supported by systematic monitoring of its implementation and evaluation.

There may be distinguished the following priority areas of the public policy:

- Strengthening of the state regulation's function for integrated development of rural areas by creating a state agency for coordination and management of the development process. It could serve as a manager of administrative and financial resources that concentrates key factors and resources for realization of economic, social, demographic, humanitarian policy in rural areas.

- Application of a three-level system of management in the rural areas development (local, regional, national) thereby separating the powers, responsibilities and resources between the authorities of different territorial administration levels, and empowering local communities to solve sustainable development issues in rural areas taking into account their local specificity.

- Formation of the partnership model of socio-economic development of rural areas through the interaction of such subjects as local government, community organizations, representatives of local businesses.

- Improvement of mutual relationships of towns and villages: urban system should be developed in such a way as to facilitate the access to them for rural residents; development of public transport networks, increasing the efficiency of infrastructure; creating recreation areas for the residents; preserving and enhancing natural and cultural heritage. The condition for such effective partnership cooperation with local authorities on the basis of equality.

- Horizontal cooperation regarding economic, financial and social policies. During the preparation of different programs and then making decisions, spatial conditions and the expected territorial impact should be taken into account.

- Interaction of sectoral policies that have a significant geographical impact, for example, on transport, agriculture and environmental protection.

- Use of territorial planning as an effective tool for integration of local, regional and national interests in certain areas.

- Creation of a mechanism for the self-development of regions and strengthening their financial and resource base.

- Establishing of an effective and efficient local government system and a strong local community. The community should maintain and develop the necessary infrastructure that would provide basic administrative and public services (water supply, sanitation, energy supply, pre-school and secondary education, social protection, road maintenance, health, medical, cultural services, etc.).

- Introducing advisory services for local government in the regional councils, as centers for interaction and managing the development of rural areas.

- Creating effective mechanisms of control by the executive authorities and local communities for monitoring the decisions and actions of local government.

The current model of revival of the Ukrainian village becomes real on the base of formation of baseline criteria (administrative and territorial units-communities). The main responsibilities of local communities for 
expenditures are as follow: provision of municipal services, territorial improvement, maintenance of local roads, local infrastructure, management of pre-school and secondary education, provision of primary health care, social security and assistance, cultural development and physical culture, disposal of land outside the settlements, area reclamation, community economic development, passenger transportation in the community, local police and fire protection, administrative and public services (Concept, 2014). Thus, determined powers are provided by the direct relations with the state budget and the following types of local budget revenues: $60 \%$ tax on personal income, $25 \%$ environmental tax, $5 \%$ excise tax, single tax, income tax, property tax, state tax, fee administrative services, administrative fines and penalties, charges (tourism, parking), fees for licenses and certificates, rent and rent for the use of natural resources and transfers, on revenues of budgetary institutions, equity funds, etc.

Yet the results of fiscal decentralization in 2015 has shown the increase of local revenues by $42.1 \%-99.8$ billion UAH against 70.2 billion UAH in 2014. In January-February of 2016, the general fund revenues of local budgets (without transfers) increased by $49.2 \%$, or 6.2 billion, compared to the same period in 2015 and amounted to 18.9 billion UAH (Zubko, 2016).

However, the State Budget for 2016 provides a subvention of 1 billion USD for the creation and modernization of the infrastructure of the united territorial communities. The subvention is provided for the creation and modernisation of the united local community infrastructure, and can be directed to new construction, reconstruction and repair of infrastructure sites, belonging to communal property (including production design and planning documentation). It is understood that social support for rural areas has no direct impact on economic growth. However, this component is a unifying factor for the rural territorial communities and creates a feeling of care from the authorities about the human and a feeling of security in difficult times.

For the first half of 2016 actual revenues of the general fund of local budgets of 159 united local communities (including transfers from the state budget) accounted for 3093 million UAH, what is seven times more compared to the 2015 budget revenues of local councils amalgamated with the ULC. Association of communities allowed increasing the ULC budget income per 1 local resident. The average ULC index (compared to the first half of 2015) increased by 667 USD (from 288 UAH to 955 UAH) (Zubko, 2016).

The concept of sustainable rural development foresees the inclusion of space (territory) into different processes: economic development should be associated with a particular territory, environmental regulations should be ensured not in general but for a particular place. Furthermore, social equality should exist in a certain community and not be abstract in average rates in the country. Such an approach forms the concept of sustainable areas development which now has a tendency to be implemented in many countries of the world.

Despite the existence of the legislative support, the coordination of the sectoral policies affecting the development of regions and territories unfortunately has not been yet created in Ukraine. Talking about modern agricultural policy of the EU we should understand that it was formed and it operates on the foundation and within the limits of the regional, primary structural policy. Regional structural policy of the EU is considered to be a good example of European multilevel interlacing. When describing the structure of regional structural policies such concepts as multi-system network or political double interlacing are used, in this way these concepts cover cooperation between the EU, member states and regions but they don't indicate the internal differentiation of this interlacing structure. However, we should pay attention if we want to understand the principles of functioning of the common European structural policy. In regional structural policy the regional structural strength depends not only on the availability of the administrative and financial resources but also on the decisions of the regional structures and their integration into vertical layered structure (Bentz, 2007).

In Ukraine during the last years a reinterpretation of the national regional policy based on the best European experience, actually rural development policy, took place and was defined as part of a policy of regional development. Therefore, today development of rural areas is considered as part of a regional policy, not as a separate one. However, for Ukraine, where the level of urbanization is one of the lowest in Europe and a part of agriculture in the GDP of the state is the highest among the European countries, rural areas development should be a priority, singled out as part of the state regional policy, maintaining social orientation and coordinated with the sectoral (branch) policies. 


\section{Conclusions}

Implementation of fiscal decentralization should be based on the administrative-territorial reform in Ukraine and a new ideology of the government which determines the primary target of the state and local government activity - to provide efficient services. While solving these important tasks there should be a search for integrated management solutions, taking into account the whole range of the existing problems - cultural, social, and economic, of legal and institutional character.

The purpose of the state regulation of rural areas development should lie in the creation of favourable conditions for the citizens, the society and the state. It will undoubtedly serve for the further progress of Ukraine as a democratic state with a stable and growing market economy governed by the European economic values, which respect and protect the rights and legitimate interests of all regional communities, social classes and ethnic groups. Thus, it is the key to independent, free, sovereign, united and democratic development of Ukraine.

\section{References}

Benz, A. (2007). Multilevel interlacing in the European Union. European integration. Kyiv: Mohyla Academy, p. 219, 224.

Bila, S. O. (2012). Reforming of the social-economic development of rural areas in Ukraine. Strategic Priorities, Vol. 3 (24), p. 62-70.

Borodina, O. (2010). Social innovation in the system of rural development: conceptual approaches. Economy of Ukraine, Vol. 9, p. 68-77.

Borschevskyy, V. V. (2012). The development of rural areas in the system of European integration priorities of Ukraine. Lviv.

Diyesperov, V. S. (2014). Rural areas as objects of economic activity. Economy of AIC, Vol. 5, p. 56.

Gogol, T. V. (2009). Rural areas as an object of state regulation [E-resource]. Public Administration: Theory and Practice, Vol. 2. Available: http: //www.nbuv.gov.ua/ej10/index.htm. Heading from the screen.

Grynchuk, N. M. (2011). Innovative approaches in addressing the socio-economic development of cities. Innovation in public management: system integration of education, science and practice: Proceedings of the conference with international participation, Vol. 2, p. 14-16.

Ermolenko, V. M. (2010). Features of formation of the category "sustainable rural development". Scientific Bulletin of National University of Life and Environmental Sciences of Ukraine, Vol. 156, p. 50-59.

Ilyina, M. (2014). Theoretical problems of study of rural area as integral socio-ecological-economic systems. Environmental Economics and Environment, p. 112-115.

Kovbasyuk, Y. V. (2011). Encyclopedia of Public Administration. Methodology of state government, Vol. 2.

Kropyvko, M. F. Organization and planning of a complex development of agricultural production and rural areas in terms of decentralization of powers [E-resource] Available: http://edorada.org/uk/node/355.

Lavrynenko, S., Zhalilo, Ya. As for the level of social development of rural areas and rural life [electronic resource]. Available: http://old.niss.gov.ua/

Malik, M. I. (2010). Sustainable development of rural areas on the basis of regional nature and environmental safety agroindustrial production. Economy of AIC, Vol. 5, p. 3-12.

Mohylnyi, O. M. (2010). State policy in the rural areas development. Economy of AIC, Vol. 10, p. 125-131.

Moskalev, I. Technological bases of social and innovation public administration [E-resource] Available: http://spkurdyumov.narod.ru/Moskalev23.htm.

Orlatyi, M. K., Gogol, T. V. (2012). Modern problems of development of social infrastructure in rural areas of Ukraine. Sustainable development and security of agricultural sector of Ukraine in conditions of globalizational challenges, p. 521-539.

Orlatyi, M. K., Hnybidenko, I. F., Demchak, I. M. (2012). Rural areas development of Ukraine (1990-2010 years). Kyiv: Research institute.

On approval of the Concept of reforming the local self-government and territorial organization of power in Ukraine, from 1.04. 2014. Number 333-r. Available: http://zakon5.rada.gov.ua/.

Pavlov, A. I. (2015). Identification and classification of agricultural territories: theory, methodology, practice. Odessa: Astroprint.

Šimanskienè, L., Paužuolienè, J. (2010). Corporate social responsibility based on sustainable business. Human Resources: The Main Factor of Regional Development, Issue 3, p. 324-331. 
Wyporska, K., Mosiej, J. (2010). Technical infrastructure for environmental protection at the level of farms as a factor of sustainable rural development. Economic and Environmental Studies, Vol. 10, No. 1 (13), p. 71-84.

Zubko, G. Thanks to the financial decentralization the revenues of local budgets increased during the year in 1.5 times [E-resource] Available: http://decentralization.gov.ua/.

\title{
MAŽIAU IŠSIVYSČIUSIŲ UKRAINOS REGIONŲ VIEŠASIS ADMINISTRAVIMAS
}

\author{
TATYANA GOGOL \\ Valstybinis žemdirbystės ir inžinerijos universitetas Podilijoje (Ukraina)
}

\section{Santrauka}

Šiuo tyrimu siekiama perteikti sudėtingą informaciją apie regionų vystymą ir jų administravimo sistemas, patirtis kuriant ir igyvendinant valstybinę regionų politiką Ukrainoje. Informacija pateikiama paprastai pripažistamų ir vertinamų konceptų bei nuomonių apie regionų vystymą ir politiką, Europos patirties ir globalių tendencijų bei krypčių kontekste. Visų pirma informacija paremta regionų ir kaimo vietovių Ukrainoje valdymo patirtimi. Straipsnyje atskleidžiama, kad norint užtikrinti efektyvų ir kompetentingą kaimo vietovés viešajị administravimą pirmiausia reikètų nusistatyti prioritetus. Prioritetai turètų būti teikiami mažiau išsivysčiusiems regionams ir tai turètų būti valstybinès regionų politikos dalis, koordinuojant savo veiksmus su sektorine politika, kartu išlaikant savo socialinę pakraipą. Fiskalinès decentralizacijos taikymas Ukrainoje turètų būti derinamas su administracine-teritorine reforma. Svarbu, kad naujos valdžios deklaruojama ideologija būtų nukreipta ị pagrindinių valstybès ir vietos valdžios problemų sprendimą, siekiant gyventojams teikti efektyvias paslaugas.

Tokio integruoto administravimo, kuris atkreiptų dèmesį ị visas skirtingas kultūrines, socialines, ekonomines, ịstatymines ir institucinio pobūdžio problemas, paieškos yra būtinos, norint išspręsti kylančias problemas.

Valstybės lygmens kaimo vietovių reguliavimo tikslas turètų būti tokių reguliavimo mechanizmų sukūrimas piliečiams, valstybei ir visuomenei, siekiant tolesnès Ukrainos, kaip demokratinès valstybès, pažangos ir ekonominio augimo, pripažistant Europos ekonomines vertybes bei atsižvelgiant ị teisètus regionų bendruomenių, socialinių klasių ir etninių grupių interesus. Tai yra kelias ị laisvos, nepriklausomos, savarankiškos, vieningos ir demokratiškos Ukrainos vystymąsi.

PAGRINDINIAI ŽODŽIAI: kaimo vietovess, viešasis administravimas, regionu politika, agrokultūros politika.

JEL CODES; H 73; H 79.

Received: 2016.11.28

Reviesed: 2017.01.02

Accepted: 2017.01.15 